\title{
Senior Tourism: Towards and Active and Healthy Ageing
}

\author{
Balderas-Cejudo María Adela*, Leeson George W and Urdaneta, Elena \\ Oxford Institute of Population Ageing, University of Oxford, UK \\ Basque Culinary Center-University of Mondragón, Spain
}

Submission: April 24, 2017; Published: April 28, 2017

*Corresponding author: Balderas-Cejudo María Adela, Oxford Institute of Population Ageing, University of Oxford, UK; Basque Culinary CenterUniversity of Mondragón, Spain, Email: abalderas@bculinary.com

\begin{abstract}
The world is undergoing an unprecedented change in its age composition [1]. The United Nations [2] has recognized the fact that the numbers of the older population are growing rapidly and it has estimated that over two billion people will be aged 60 years and over by the year 2050, which will account for $22 \%$ (or one out of five) of the world's population, compared to $10 \%$ in 2000 . Both practitioners and researchers have acknowledged the importance of older adults as a significant market segment. Nevertheless, there is a gap in the literature and within academic research on role that holidays play within health and wellbeing. A general overview on the importance of this issue and the relevance of gaining understanding on the relationships between tourism, leisure travelling and its influence on health and active ageing is being reported.
\end{abstract}

\section{Introduction}

Population ageing is a well-known phenomenon in most developed countries, where the proportion of older people has been steadily growing over the past century [3]. In addition, different regions of the world-and even different countries with in regions-have experienced the demographic ageing of their populations in significantly different ways [4]. Forecasts estimate that the number of people over 60 will more than double to constitute $22 \%$ of the world's population by 2050 [5,6]. In 2002, almost 400 million people aged 60 and over lived in the developing world. By 2025, this will have increased to approximately 840 million representing 70 per cent of all older people worldwide [7]. The ageing of populations in most western countries and in many non-western countries, as well as changes in older adults' socio-demographics and travel patterns, have made the older segment an appealing target population for the global tourism and travel industry [8-10].

As a direct consequence of these global ageing patterns, senior travelers are increasingly accounting for a larger share of all vacation spending globally [11-13]. In recent years, both practitioners and researchers have acknowledged the importance of older adults as a significant market segment in the tourism industry [6,14-16]. The ageing of populations in most western countries and in many non-western countries, as well as changes in older adults' socio-demographics and travel patterns [17], have made the older segment an appealing target population for the global tourism and travel industry $[8-10,18]$.
Academic researchers and destination managers are beginning to recognize the importance of older people being identified as a group of people who can benefit from tourism experiences [21] and in particular baby boomers (born between 1946 and 1964) of the tourism and hospitality industry. Furthermore, recent studies on boomers have shown that there has been a paradigm shift in terms of the unique characteristics of baby boomer tourists compared to other generations [18].

In this context, the aim of the current study is to gain understanding on the relationships between tourism, leisure travelling and its influence on health and active ageing. The role that holidays play within health and wellbeing, the links between healthy and active lifestyles and travel experience have been addressed infrequently within academic research $[19,20]$. Moreover, the context of research on senior travellers, whilst there have been many studies on the general characteristics of this market, there are fewer which have focused on health and wellbeing relationships for this group [20,21]. Concluded in his study that research tended to focus more on the physical wellbeing of older adults, and he stated that there is a greater need to more fully explore the influence of travel experiences on older adults' well-being, including their spiritual and psychological well-being. Similarly, [22] suggested that there is a need to explore the interrelationship between leisure (travel), personal reflections of life experiences and their impact on life satisfaction and well-being. 
A deeper analysis in the literature may give a greater view of the senior travellers not only as an attractive and evolving market segment for the tourism industry but also considering senior tourism as a strategy and tool towards an active and healthy ageing.

\section{Summary of Research Findings}

In an attempt to learn more on the relationship between senior tourism and health, a literature review was conducted focused on (1) active ageing (2) healthy ageing (3) wellbeing connected with (5) holiday travelling and (6) the elderly. Generally, today's seniors are healthier, richer, more educated, more independent and free from obligations than older people in the past $[10,23,24]$. They are also distinct from former cohorts of seniors because many of them have travel experience, both in groups and alone, in connection with their work lives as well as a result of travelling for pleasure [25].

The leisure travel and tourism industry is one specific area where the senior segment of the population has significant impact [26]. Satisfaction with life has been shown to be linked to satisfaction with leisure travel services and experiences, and more general links between tourism and quality of life [27], and subjective well-being have been made $[10,28]$ state that leisure plays a key role in older adults' wellbeing. Thus, remaining actively engaged with life in older adulthood is considered a key aspect of healthy aging [29,30]. A large body of research and theoretical literature confirms that physical, cognitive, and social functioning, broadly speaking, are key factors of successful aging and that multiple lifestyle choices, behaviours, and psychosocial factors influence them [31].

Leisure has a positive influence on the lives of elderly people and, in particular, their satisfaction with life [32]. Moreover, in an analysis of the optimization of quality of life potentials for the aged in the 21st century, leisure activities were ranked as a top priority (Riley 1992). As some researchers state, the interests and desires of the elderly are satisfied through leisure [33,34] and more concretely [32] confirm that the right type of leisure can help seniors' physical and mental fitness and lead to greater life satisfaction.

According to Ferrer et al. [20], it is generally accepted that holiday tourism is a positive and healthy pursuit to follow in leisure time (Hobson and Dietrich 1995), providing many benefits to mental and psychical health. Across a range of contexts, the links between holiday taking and quality of life, health, stress reduction, active life and healthy lifestyle have been demonstrated. Travel has been positively correlated with physical health outcomes (specifically, risk of cardiovascular heart disease amongst middle-aged men) [35]. People often feel happier, healthier and more relaxed after a pleasure trip, although these effects are limited in strength and duration after the holiday. Furthermore Kim, Woo and Uysal [36] note, in the leisure industry, many studies have supported activity theory and demonstrated that elderly people's high level of involvement and activity contributes to their quality of life [37-39].

\section{Practical Implications and Further Research}

Based on the findings above, remaining actively engaged is crucial for an active ageing (Katz 2013). Health can be both motivator and constraint regarding leisure travelling and seniors. It is essential to genuinely understand this relevant market segment so as to cater for their needs, wants and expectations not only from a marketing and sales perspective but also as a strategy towards a healthier ageing. Although there are researchers that confirm that travel can be an enriching experience in the lives of seniors $[32,40]$, the role that holidays play within health and wellbeing has been addressed infrequently within academic research [19]. Even though several studies have investigated how tourism experiences of elderly affect their quality of life, there is still limited research on the link between senior tourism to an active and healthy ageing. As Tung et al. (2011) noted, the senior travel market is one of the most challenging for scholars to understand due to its inherent complexities. Accounting for the needs, expectations and desires of a mature market in a proactive way may contribute to innovative ways to address some of the gaps identified in the literature as it is the need to understand the wants of an ageing population; the need to expand knowledge of the trends underpinning tourism development and the need to analyze the effects of tourism as an strategy towards an active and healthy ageing.

\section{References}

1. Harper S (2016) How Population Change Will Transform Our World. Oxford University Press. India.

2. United Nations, Department of Economic and Social Affairs, Population Division (2015). World Population Prospects. New York, USA.

3. Harper S, Leeson G (2008) "Introducing the journal of population ageing". Journal of Population Ageing 1(1): 1-5.

4. Leeson GW (2016) Environment, Health and Ageing. In Environmental Gerontology in Europe and Latin America (pp. 93-104).

5. Magnus G (2009) The age of ageing. Singapore: Asia.

6. Sedgley D, Pritchard A, Morgan N (2011) "Tourism and ageing: A transformative research agenda". Annals of Tourism Research 38(2): 422-436.

7. WHO (2002) Active ageing: A policy framework. Geneva, Switzerland.

8. Patterson I (2006) Growing older. Tourism and leisure behaviour of older adults. Cambridge: UK.

9. Schröder A, Widmann T (2007) Demographic Change and its impact on the travel industry: Oldies-nothing but goldies? In R. Conrady \& M. Buck (eds.), Trends and issues in global tourism pp: 3-17.

10. Nimrod G, Rotem A (2010) Between relaxation and excitement: Activities and benefits gained in retirees' tourism. International Journal of Tourism Research 12(1): 65-78.

11. Balderas-Cejudo A, Rivera-Hernaez O, Patterson I (2016) The Strategic Impact of Country of Origin on Senior Tourism Demand: the Need to Balance Global and Local Strategies. Journal of Population Ageing 9(4): 345-373. 
12. Littrell M A, Paige RC, Song K (2004) "Senior travellers: Tourism activities and shopping behaviours". Journal of Vacation Marketing 10(4): 348-362.

13. Wang K C, Chen J S, Chou SH (2007) Senior tourists' purchasing decisions in group package tour. Anatolia 18(1): 23-42.

14. Fleischer A, Pizam A (2002) "Tourism constraints among Israeli seniors". Annals of Tourism Research 29(1): 106-123.

15. Nimrod G (2008) "Retirement and tourism themes in retirees' narratives". Annals of Tourism Research 35(4): 859-878.

16. Nyaupane, Gyan P, James T, McCabe, Kathleen L Andereck (2008) "Seniors' travel constraints: Stepwise logistic regression analysis." Tourism Analysis 13 (4): 341-354.

17. Urdaneta E (2016) SIforAGE: Social Innovation for healthy and active ageing for an economic growth. www.siforage.eu

18. Kazeminia, Azadeh, Giacomo Del Chiappa, Jafar Jafari (2015) “Seniors' travel constraints and their coping strategies." Journal of Travel Research 54(1): 80-93.

19. Patterson I, Balderas-Cejudo A, Rivera-Hernaez O (2017) Changing trends in the baby boomer travel market: importance of memorable experiences. Journal of Hospitality Marketing \& Management 1-14.

20. Hunter-Jones P (2003) "The perceived effects of holiday-taking upon the health and wellbeing of patients treated for cancer". International Journal of Tourism Research (5):183-196.

21. Ferrer JG, Sanz MF, Ferrandis ED, McCabe S and García JS (2015) Social tourism and healthy ageing. International Journal of Tourism Research.

22. Dann GMS (2001) “Senior tourism”. Annals of Tourism Research 28(1): 235-238.

23. Mannell RC (2014) Leisure in the laboratory and other strange notions: Physiological research on the subjective nature of leisure. In S. Elkington \& S. J. Gammon (Eds.), Contemporary perspectives in leisure: Meanings, motives and lifelong learning (pp. 3-27).

24. Martin, Linda G, Samuel H Preston eds (1994) Demography of aging. National Academies Press.

25. Zimmer Z, Brayley R E, Searle MS (1995) "Whether to go and where to go: Identification of important influences on seniors' decisions to travel". Journal of travel research 33(3): 3-10.

26. Hayslip B, J Hicks-Patrick, P Panek (2007) Adult Development and Aging. Malabar, FL: Krieger Publication PP: 398.
27. Shoemaker S (1989) "Segmentation of the senior pleasure travel market". Journal of Travel Research 27(3): 14-21.

28. Dolnicar, Sara, Venkata Yanamandram, Katie Cliff (2012)"The contribution of vacations to quality of life." Annals of Tourism Research 39 (1): 59-83.

29. Gilbert D, Abdullah J (2002) "A study of the impact of the expectation of a holiday on an individual's sense of well-being". Journal of Vacation Marketing 8(4): 352-361.

30. Menec Verena H (2003) "The relation between everyday activities and successful aging: A 6-year longitudinal study." The Journals of Gerontology Series B: Psychological Sciences and Social Sciences 58 (2): S74-S82.

31. Hutchinson SL, Nimrod G (2012) Leisure as a resource for successful aging by older adults with chronic health conditions. The International Journal of Aging and Human Development 74(1): 41-65.

32. Franklin Nina C, Charlotte A Tate (2009) "Lifestyle and successful aging: An overview." American Journal of Lifestyle Medicine 3(1): 6-11.

33. Lee SH, Tideswell C (2005) "Understanding attitudes towards leisure travel and the constraints faced by senior Koreans". Journal of Vacation Marketing 11(3): 249-263.

34. Tinsley HEA, Tinsley DJ (1986) 'A Theory of the Attributes, Benefits, and Causes of Leisure Experience'. Leisure Studies 8(1): 1-45.

35. Coleman D, Iso-Ahola SE (1993) 'Leisure and Health: The Role of Social Support and Self-Determination'. Journal of Leisure Research 25(2): 111-128.

36. Gump BB, Matthews KA (2000) Are vacations good for your health? The 9-year mortality experience after the multiple risk factor intervention trial. Psychosomatic Medicine 62(5): 608-612.

37. World Population Ageing 2015 (ST/ESA/SER.A/390).

38. Fernandez-Ballesteros, Zamarron, Ruiz (2001) "The Contribution of Socio-Demographic and Psychosocial Factors to Life Satisfaction". Ageing and Society 21(1): 25-43.

39. Iso-Ahola SE, Jackson E, Dunn E (1994) “Starting, ceasing and replacing leisure activities over the life-span". Journal of Leisure Research 26(3): 227-249.

40. Kim H, Woo E, Uysal M (2015) Tourism experience and quality of life among elderly tourists. Tourism Management 46: 465-476.

41. Teaff JD (1985) Leisure Services with the Elderly. St Louis: USA.

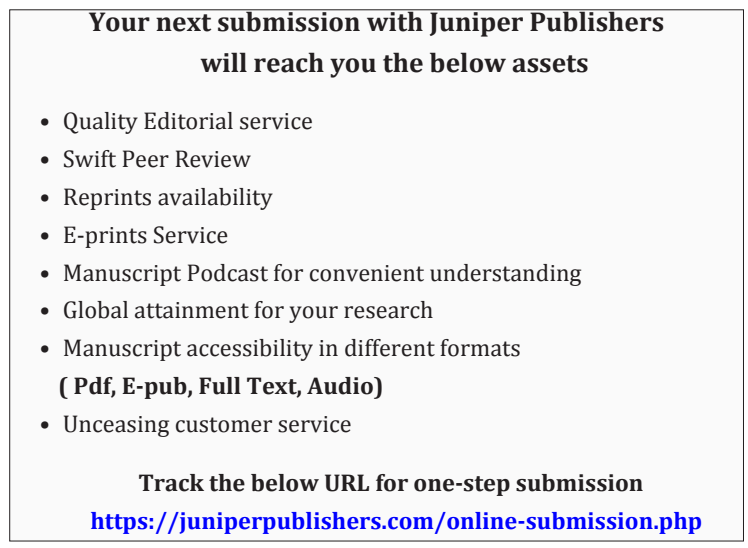

